\title{
Avian responses to forest fragmentation during the breeding and non-breeding seasons
}

\author{
ERNESTO GUSTAVO VERGA ${ }^{1 * \dagger}$ (iD) LEONARDO GALETTO ${ }^{1}$ \& SUSANA INÉS PELUC ${ }^{2}$ \\ ${ }^{1}$ Instituto Multidisciplinario de Biología Vegetal, Universidad Nacional de Córdoba-CONICET, Av. Vélez Sársfield \\ 1611, Córdoba, Argentina \\ ${ }^{2}$ Instituto de Diversidad y Ecología Animal, Centro de Zoología Aplicada, Universidad Nacional de Córdoba - \\ CONICET, Rondeau 798, Córdoba, Argentina
}

\begin{abstract}
Forest fragmentation represents a threat to several bird species worldwide. Several factors can change across seasons (e.g. bird perception of the landscape, weather conditions, biotic interactions), which can modify the response of bird populations to forest fragmentation. However, most studies have been conducted only during the breeding season. Here we assessed the relationship between forest fragmentation (patch area and patch isolation) with population abundances of resident species during both the breeding and the non-breeding seasons. Bird population abundances (all species in the community, subsets of forest and habitat generalist species and for individual species) were estimated across a gradient of area-isolation in a semi-arid forest in Cordoba, Argentina. Population abundance of the overall avian community and of the subset of forest species declined with patch area reduction independently of the season. By contrast, the subset of habitat generalist species was not affected by patch area reduction or by the increase in patch isolation, either during the breeding or during the non-breeding season. When the analyses were carried out for individual species, we found four forest species and one habitat generalist species whose responses (the relationship between population abundance and patch area or with isolation) were different between breeding and non-breeding seasons. The negative effects of forest fragmentation were found mainly during the breeding season. Our results suggest that reduction of patch area may lead to a reduction of more than $65 \%$ of the population abundance of forest bird species, during both the breeding and the non-breeding season. Therefore, there is an urgent need to conserve large forest patches within the region as irreplaceable elements for the conservation of populations of several species.
\end{abstract}

Keywords: generalist, habitat, isolation, patch area, seasonal effects, specialist.

Birds are one of the most frequently studied groups in the context of forest fragmentation (Turner 1996, Bennett et al. 2006, Fardila et al. 2017). However, bird responses to forest fragmentation have been examined mostly during the breeding season (spring-summer), disregarding other periods

\footnotetext{
${ }^{\dagger}$ Present address: Instituto de Diversidad y Ecología Animal Centro de Zoología Aplicada Universidad Nacional de Córdoba - CONICET Rondeau 798 Córdoba Argentina

*Corresponding author.

Email: ernesver@gmail.com

Twitter: @ErnestoGVerga
}

of the year (Nour et al. 1999, Murgui 2007, Caprio et al. 2009, Fraixedas et al. 2015). Consequently, our understanding of forest fragmentation effects on bird populations is partial and mainly restricted to the reproductive period (Nour et al. 1999). Several processes that affect bird populations may change seasonally, including food availability, predation risks, habitat use, movement patterns and territoriality, so bird population responses to forest fragmentation may vary accordingly (Keller \& Yahner 2007, Lenz et al. 2015). For example, edge effects on nest predation and brood parasitism risk are restricted to the breeding season. Similarly, 
during the breeding season, birds tend to be restricted to local ecological conditions or within territories, whereas during the non-breeding season, many bird species show less territorial defence (Nour et al. 1999) and may have increased homerange sizes (Wiktander et al. 2001, Lenz et al. 2015). Therefore, during the non-breeding season, isolated or small forest patches not suitable for reproduction are more likely to be visited and used (Nour et al. 1999, Murgui 2007). On the other hand, because small forest patches have limited capacity to buffer abiotic conditions (Murgui 2007), the effects of patch area reduction on bird populations could be more evident during the winter, when weather conditions are more severe than during the breeding season in temperate and subtropical regions (Nour et al. 1999, Murgui 2007). Consequently, it is important to compare fragmentation patterns for birds in both breeding and nonbreeding seasons better to understand forest fragmentation effects on bird populations (Nour et al. 1999, Murgui 2007).

Previous studies have not shown clear patterns in bird population responses to forest fragmentation across different seasons (Nour et al. 1999, Caprio et al. 2009, Naoe et al. 2011, 2012). Some authors have reported negative responses of birds to forest fragmentation only during the breeding season (i.e. a decrease of bird abundance in fragmented forests relative to a continuous forest reserve, Naoe et al. 2011, and a greater occurrence and persistence in continuous forest than in forest patches, Lenz et al. 2015). On the other hand, Caprio et al. (2009) found that bird abundance was influenced by forest fragmentation, considering a combination of several landscape-level predictors of forest fragmentation, but only during the non-breeding season. Other authors have detected consistent trends across seasons (i.e. a decrease of bird richness and occurrence in association with an increase in the degree of forest fragmentation, Nour et al. 1999, or a decrease of species richness with a reduction of patch area, Murgui 2007, Yamaura et al. 2009). However, Morgado et al. (2010) observed avian population declines in relation to habitat fragmentation (i.e. habitat amount and patch area) that were more pronounced during the non-breeding period. This variety of responses observed in different periods of the year highlights the need to study patterns of population change in the forest fragmentation context during both the breeding and the non-breeding seasons to formulate a more complete assessment of the effect of forest fragmentation on bird populations (Siffczyk et al. 2003, Robb et al. 2008). To assess possible variations of avian responses to forest fragmentation across seasons, it is necessary to study resident species in the same sites but during different times of the year.

In addition to seasonal changes in bird responses to forest fragmentation, specific life history traits may also affect changes in population abundances in relation to forest fragmentation (Henle et al. 2004, Dardanelli et al. 2006, Bregman et al. 2014, Morante-Filho et al. 2015). In this sense, forest specialists in general are more prone to decline as a response to habitat fragmentation (because their needs are restricted to forest habitats) than habitat generalist species, which are able to use open areas, degraded or treeless areas, and are less sensitive or even favoured by forest fragmentation (Asefa et al. 2017).

Forests of the Chaquean dominium in South America, in which the phytogeographical regions of the Chaco forest and the Espinal are included (Lewis et al. 2009), are one of the most endangered worldwide as a result of forest clearance and fragmentation, mostly due to agricultural expansion (Hansen et al. 2013, Schmidt 2015). Both phytogeographical regions are characterized by woodland and grassland vegetation distributed as a mosaic across the landscape (Bucher 1982, Cabido et al. 2018). Woody vegetation in the Chaco forest is dominated by Schinopsis spp. and Aspidosperma quebracho-blanco, whereas the Espinal is dominated by species of Prosopis (Bucher 1982, Cabido et al. 2018). In the most austral distribution of these forests (located in Cordoba province), land conversion has been so high that more than 1000000 ha of seasonal, semi-arid forest has been lost between 1970 and 2000, a loss of 85\% of the original Chaco forest in the province (Zak et al. 2004, Hoyos et al. 2013). Despite this scale of forest loss and fragmentation, forest remnants still host a great diversity of birds (Dardanelli et al. 2006, Giraudo et al. 2006, Salvador et al. 2016, Table S1). Small forest patches (approximately $1 \mathrm{ha}$ ) can host most of the bird species found in larger patches (approximately 300 ha), suggesting that such a community is resilient to forest fragmentation (Dardanelli et al. 2006). However, a recent study showed that common bird species were considerably less abundant in smaller and more isolated patches (Verga et al. 2017). 
We tested the hypothesis that forest fragmentation (measured as patch area reduction and increase of patch isolation) will be negatively related to population abundance of bird species but that this effect will vary between breeding and non-breeding seasons. However, because previously reported trends of avian populations in response to forest fragmentation in different seasons are unclear, we were unable to make specific predictions. Recognizing this uncertainty, we describe changes in population abundances of different assemblages (the overall avian community, subsets of forest species and of habitat generalist species) and of individual species separately, to assess bird population changes in relation to forest fragmentation during both the breeding and the non-breeding seasons.

\section{METHODS}

\section{Study area}

The study area is included in the Chaquean dominium (Lewis et al. 2009), particularly in an ecotone between semi-arid Chaco Forest and Espinal, Cordoba, Argentina. The climate is seasonal, with precipitation concentrated in the warm season (50$200 \mathrm{~mm}$ monthly) and scarce during the winter (0-70 mm monthly). The mean temperature is approximately $23^{\circ} \mathrm{C}$ in summer and $11^{\circ} \mathrm{C}$ in winter (Gavier \& Bucher 2004). The study area has been transformed into an agricultural ecosystem. Currently, natural vegetation is restricted to forest patches of different size and degree of isolation immersed in an agricultural matrix (Fig. S1): mainly soybean Glycine max and maize Zea mays in the summer and wheat Triticum aestivum during the winter (Grilli \& Galetto 2009). Forest patches have been isolated for at least 40 years (González et al. 2018). During the winter, some fields have only the stubble of the summer cultures. Dominant trees species within the forest patches are Prosopis nigra, Prosopis alba, Celtis ehrenbergiana, Geoffroea decorticans, Senegalia praecox and Aspidosperma quebracho-blanco. In addition, some exotic tree species such as Ulmus spp., Melia azedarach, Broussonetia papyrifera, Gleditsia triacanthos, Morus spp. and Ligustrum lucidum are common. The most common native shrub species are Vachellia caven, Schinus fasciculatus, Jodina rhombifolia, Porlieria microphylla and Condalia microphylla (Ferreras et al. 2008, Ferreras \& Galetto 2010, Grilli et al. 2014). The sites selected for study shared a similar vegetation structure to minimize possible effects of vegetation heterogeneity on the response variables. In other words, all the forest patches have a complex structure, with arboreal, shrubby and herbaceous strata (Grilli et al. 2013, Díaz Vélez et al. 2015). Moreover, forest patches are not managed for timber production or other purposes.

We selected forest patches representing a combined gradient of patch area (from 0.4 to $830 \mathrm{ha}$ ) and isolation (from 20 to $1700 \mathrm{~m}$ ). Specifically, the areas of the forest patches were $0.4,0.5,0.7,1.4$, $1.6,1.8,11.5,13.6,16.5,16.8,18.0,18.9,495$ and 830 ha in size. We estimated patch isolation as the average distance between a patch and the three closest woodland patches of any size (Radford \& Bennett 2004). We conducted avian surveys in a total of 14 forest patches. Seven forest patches were located within the Estancia Santo Domingo $\left(31.18^{\circ} \mathrm{S}, 64.26^{\circ} \mathrm{W}\right)$ and seven were located within

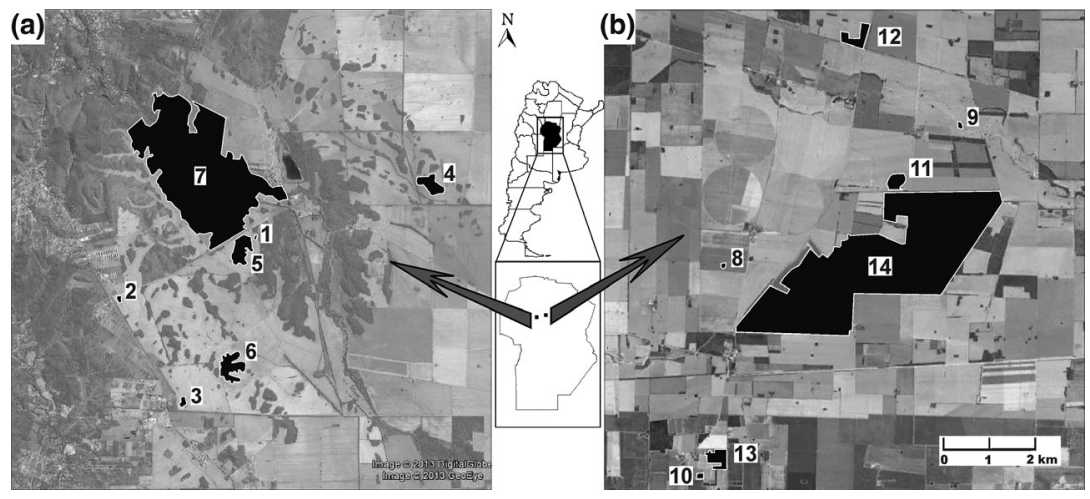

Figure 1. Location of the study area in Córdoba province (shaded in black), Argentina. The black rectangles within the map show the location of the two regions: (a) Santo Domingo, and (b) Comuna Tinoco. The forest patches sampled are indicated in black. 
the Comuna Tinoco $\left(31.10^{\circ} \mathrm{S}, 63.87^{\circ} \mathrm{W}\right)$ (Fig. 1). Both regions are in the centre of Cordoba Province, $40 \mathrm{~km}$ apart (Verga et al. 2017).

\section{Bird surveys}

We conducted surveys during two consecutive breeding seasons (from December 2011 to early April 2012, and December 2012 to early April 2013) and two non-breeding seasons (from July to early September during the winters of 2012 and 2013). We estimated abundance of bird species by means of fixed-radius point counts, conducted between 06:00 and 10:00 $\mathrm{h}$ and between 17:00 and 20:00 h. We recorded the presence and abundance of all birds seen or heard at each point within a $50-\mathrm{m}$ radius, during a period of $10 \mathrm{~min}$. We did not include birds flying over the area. We conducted 20 point counts per patch during the summer (12 point counts in 2011-2012 and eight in 2012-2013) and 16 point counts per patch during the winter (eight per season during 2012 and 2013). We randomly selected the location of each point using ARCGIS 9.3 software (ESRI 2009) and then accessed the point in the field with a Global Positioning System. Overall, we conducted 504 counts throughout the study.

\section{Data analysis}

To compare changes in bird abundances in response to forest fragmentation between seasons, we selected bird species based on two criteria: first, from the overall number of species registered during the surveys (total species registered $=83$, see Table S1 for details), we selected those species that are resident in the area (Dardanelli et al. 2006, Salvador et al. 2016). In addition, we selected only those species that were recorded in at least three of the 14 forest fragments (in both seasons), in order to allow statistical comparisons in the species-by-species analysis (see below). After applying these two criteria, 28 species were included in the analysis, which we now refer to as the overall species complement of the avian community. Of those 28 species, 12 were considered habitat generalists (species that occur both in woodlands and in open areas) and 16 were considered forest species (Dardanelli et al. 2006, Salvador et al. 2016, Table 1). We refer to forest species as those that occur mainly in the forest but are not necessarily restricted to it, because they
Table 1. Model selection process based on AIC criterion. Final models are indicated in bold (the one with the lowest AIC value).

\begin{tabular}{|c|c|c|}
\hline Species & Model & $\mathrm{AIC}$ \\
\hline \multicolumn{3}{|l|}{ Species groups } \\
\hline \multirow[t]{3}{*}{ Overall species } & Model 1 & 135.9 \\
\hline & Model 2 & 134.1 \\
\hline & Model 3 & 140.9 \\
\hline \multirow{3}{*}{ Forest species } & Model 1 & 83.7 \\
\hline & Model 2 & 83 \\
\hline & Model 3 & 90.7 \\
\hline \multirow[t]{3}{*}{ Habitat generalist species } & Model 1 & 124.8 \\
\hline & Model 2 & 123.9 \\
\hline & Model 3 & 127.7 \\
\hline \multicolumn{3}{|l|}{ Forest species } \\
\hline \multirow[t]{3}{*}{ Crypturellus tataupa } & Model 1 & -23.6 \\
\hline & Model 2 & -24.2 \\
\hline & Model 3 & -5.7 \\
\hline \multirow[t]{3}{*}{ Leptotila verreauxi } & Model 1 & 11.9 \\
\hline & Model 2 & 11 \\
\hline & Model 3 & 11.5 \\
\hline \multirow[t]{3}{*}{ Colaptes melanochloros } & Model 1 & -55.4 \\
\hline & Model 2 & -57.7 \\
\hline & Model 3 & -55.9 \\
\hline \multirow[t]{3}{*}{ Thamnophilus caerulescens } & Model 1 & -8 \\
\hline & Model 2 & -10.2 \\
\hline & Model 3 & 1.3 \\
\hline \multirow{3}{*}{ Taraba major } & Model 1 & -10 \\
\hline & Model 2 & -6.8 \\
\hline & Model 3 & -11.6 \\
\hline \multirow[t]{3}{*}{ Pseudoseisura lophotes } & Model 1 & -14.4 \\
\hline & Model 2 & -17.6 \\
\hline & Model 3 & -11.5 \\
\hline \multirow{3}{*}{ Stigmatura budytoides } & Model 1 & -23.4 \\
\hline & Model 2 & -23.9 \\
\hline & Model 3 & -20.8 \\
\hline \multirow[t]{3}{*}{ Serpophaga subcristata } & Model 1 & -25.2 \\
\hline & Model 2 & -21.8 \\
\hline & Model 3 & -16.7 \\
\hline \multirow[t]{3}{*}{ Phytotoma rutila } & Model 1 & 16 \\
\hline & Model 2 & 14 \\
\hline & Model 3 & 12.7 \\
\hline \multirow{3}{*}{ Cyclarhis gujanensis } & Model 1 & -8.8 \\
\hline & Model 2 & -11.6 \\
\hline & Model 3 & 0.8 \\
\hline \multirow[t]{3}{*}{ Polioptila dumicola } & Model 1 & 5.5 \\
\hline & Model 2 & 2.9 \\
\hline & Model 3 & 1.8 \\
\hline \multirow{3}{*}{ Sicalis flaveola } & Model 1 & 25.6 \\
\hline & Model 2 & 25.4 \\
\hline & Model 3 & 22 \\
\hline \multirow[t]{3}{*}{ Coryphospingus cucullatus } & Model 1 & -1.9 \\
\hline & Model 2 & -4.6 \\
\hline & Model 3 & -3.1 \\
\hline \multirow[t]{3}{*}{ Poospiza nigrorufa } & Model 1 & -62.3 \\
\hline & Model 2 & -63.2 \\
\hline & Model 3 & -64.2 \\
\hline
\end{tabular}

(continued) 
Table 1. (continued)

\begin{tabular}{|c|c|c|}
\hline Species & Model & AIC \\
\hline \multirow[t]{3}{*}{ Thraupis bonariensis } & Model 1 & 15.1 \\
\hline & Model 2 & 12 \\
\hline & Model 3 & 11.4 \\
\hline \multirow[t]{3}{*}{ Saltator aurantiirostris } & Model 1 & 20.5 \\
\hline & Model 2 & 20.2 \\
\hline & Model 3 & 24.7 \\
\hline \multicolumn{3}{|l|}{ Habitat generalist species } \\
\hline \multirow[t]{3}{*}{ Patagioenas maculosa } & Model 1 & 45.2 \\
\hline & Model 2 & 43.4 \\
\hline & Model 3 & 50.9 \\
\hline \multirow[t]{3}{*}{ Patagioenas picazuro } & Model 1 & 13.1 \\
\hline & Model 2 & 9.2 \\
\hline & Model 3 & 14.5 \\
\hline \multirow[t]{3}{*}{ Zenaida auriculata } & Model 1 & 33.8 \\
\hline & Model 2 & 33.1 \\
\hline & Model 3 & 33.8 \\
\hline \multirow[t]{3}{*}{ Columbina picui } & Model 1 & 39.6 \\
\hline & Model 2 & 37.5 \\
\hline & Model 3 & 36.3 \\
\hline \multirow{3}{*}{ Myiopsitta monachus } & Model 1 & 41.6 \\
\hline & Model 2 & 38 \\
\hline & Model 3 & 42.1 \\
\hline \multirow[t]{3}{*}{ Furnarius rufus } & Model 1 & -15.1 \\
\hline & Model 2 & -16.8 \\
\hline & Model 3 & -14.9 \\
\hline \multirow[t]{3}{*}{ Pitangus sulphuratus } & Model 1 & 9.4 \\
\hline & Model 2 & 8.2 \\
\hline & Model 3 & 9.2 \\
\hline \multirow[t]{3}{*}{ Troglodytes aedon } & Model 1 & 4.2 \\
\hline & Model 2 & 3.9 \\
\hline & Model 3 & 5 \\
\hline \multirow[t]{3}{*}{ Zonotrichia capensis } & Model 1 & 16.2 \\
\hline & Model 2 & 12.9 \\
\hline & Model 3 & 12.5 \\
\hline \multirow[t]{3}{*}{ Agelaioides badius } & Model 1 & 31.9 \\
\hline & Model 2 & 29.4 \\
\hline & Model 3 & 28 \\
\hline \multirow[t]{3}{*}{ Molothrus bonariensis } & Model 1 & 14 \\
\hline & Model 2 & 14.6 \\
\hline & Model 3 & 16.1 \\
\hline \multirow[t]{3}{*}{ Molothrus rufoaxillaris } & Model 1 & 20.9 \\
\hline & Model 2 & 17 \\
\hline & Model 3 & 17.1 \\
\hline
\end{tabular}

Some final models for particular species (i.e. Crypturellus tataupa, Poospiza nigrorufa, Serpophaga subcristata and Troglodytes aedon) were selected based on the model assumptions, because, although there was another model with lower AIC value, it did not comply with model assumptions.

are also able to use other elements of the landscape but at a lower frequency (Yzurieta 1995, Salvador et al. 2016).

We calculated a single measure of per-patch abundance for (1) all birds, (2) all forest specialist and generalist birds separately, and (3) each species independently, by dividing the total count in each patch by the number of point counts undertaken $(n=20$ for the breeding season, and $n=16$ for the non-breeding season). We collapsed all the data of abundance into a single value (i.e. mean abundance) because point counts within each forest patch were not independent (to avoid pseudoreplication). In summary, we worked with a mean per-patch abundance corresponding to data collected across two breeding seasons, and with a mean per-patch abundance calculated from data collected across the two non-breeding seasons.

To test the relationship between forest fragmentation and bird abundance (for all birds, for forest specialists and habitat generalists, and for individual species), and to examine whether these relationships were different between seasons, we used linear mixed models. Because we conducted surveys in the same 14 forest patches during both the breeding and the non-breeding seasons, we included in the model the identity of such forest patches as a random effect (Zuur et al. 2009). That is, the use of a random effect in a mixed model allowed us to specify that data collected during the breeding season in a forest patch are not independent of data collected during the nonbreeding season in the same forest patch. To minimize the unexplained error in the models, we considered the regions (with two levels: Santo Domingo and Tinoco) as a fixed, categorical effect (block). This term was considered an additive factor in the models because explanatory data analyses suggested no interaction between region and fragmentation parameters. Because point counts within a forest patch were summarized in a single value (mean abundance), the response variable became a continuous variable. Therefore, models were run with a Gaussian distribution of the errors. To meet model assumptions, we log-transformed $\left(\log _{10}\right)$ abundances of the three groups of species (i.e. overall species, forest species, and habitat generalist species). In the species-by-species analyses, we transformed $\left(\log _{10}\right.$ or square root) the population abundances for some species to meet assumptions. In summary, for the three groups of species and for each bird species individually, we tested three models:

Model 1: abundance $\sim$ patch area + patch isolation + patch area ${ }^{*}$ season + patch isolation * season 
Model 2: abundance $\sim$ patch area + patch area $*$ season

Model 3: abundance $\sim$ patch isolation + patch isolation * season

In all models, the relationship between the response variable (abundance) and the different explanatory variables is symbolized by $\sim,{ }^{*}$ symbolizes an interaction term and + indicates an additive effect.

In model 1, we tested the main effect of patch area (covariate: area in ha), patch isolation (covariate: distance in $\mathrm{m}$ ) and the interaction between both factors with the season (categorical effect). In model 2, we tested only the main effect of patch area and its interaction with the season. In model 3 , we tested only the main effect of isolation and its interaction with the season.

For each group of species and for each bird species we selected the model with the lowest Akaike information criterion (AIC) value (Table 1). However, for four species (see Table 1 for details), the model with the lowest AIC value did not meet model assumptions (i.e. normality or homogeneity). In such cases, we compared the three models $(1,2$ and 3$)$ and selected the model which best matched the model assumptions, which is also a valid selection criterion (Zuur et al. 2009). That is, if the inclusion of some omitted variable improves the model assumption (i.e. normality, homogeneity or independence distribution of residuals), we included the variable in the final model (Zuur et al. 2009). Table 1 shows the AIC value for each of the three models per bird species, and we have marked in bold which of the three models were selected as the final one. We checked for spatial autocorrelation in the residuals of the models. For that, we followed Zuur et al. (2009). The models for the three groups of species and for 26 of 28 studied species did not show spatial autocorrelation. However, the models for two species, Blueand-yellow Tanager Thraupis bonariensis and Saffron Finch Sicalis flaveola, did show spatial autocorrelation. Therefore, we included the autocorrelation structure in the models for those species (Zuur et al. 2009). We used the free software R (R Core Team 2016 version 3.2.5) for data analysis, using the nlme package (Pinheiro et al. 2015) to run the mixed models and the MuMIn package (Barton 2016) to obtain the AIC values.

Based on the species-by-species analysis, for those species which showed an interaction between forest fragmentation and season, we constructed a scatter plot showing the relationship between its abundance and forest fragmentation (patch area or isolation) during both the breeding season and the non-breeding season, to visualize how this relationship changed across seasons.

The avian taxonomy follows Gill and Donsker (2019).

\section{RESULTS}

We registered 4205 individuals of the 28 selected species. We found effects of forest fragmentation for two groups of species (overall species and forest species; Table 2, Fig. 2). Patch area was the only explanatory variable selected in the best models for all three groups of species (overall species, forest species and habitat generalist species), whereas patch isolation was not selected in any case. Patch area was positively related to total population abundance over all species, independently of the season (Table 2, Fig. 2). Similarly, patch area was positively related to population abundance of forest species in both seasons. However, the interaction term between patch area and season was marginally significant $(P=0.058$; Table 2). Patch area was not significantly related to population abundance of habitat generalist species in any of the seasons (Table 2, Fig. 2).

When we considered responses of individual species to forest fragmentation, we found idiosyncratic patterns. The population abundances of some forest species, such as Green-barred Woodpecker Colaptes melanochloros, Variable Antshrike Thamnophilus caerulescens, Brown Cacholote Pseudoseisura lophotes, Greater Wagtail-Tyrant Stigmatura budytoides and Rufous-browed Peppershrike Cyclarhis gujanensis, were positively related to patch area, independently of the season (Table 2). Similarly, the relationship between forest patch area and population abundance of other forest species, such as Tataupa Tinamou Crypturellus tataupa and Golden-billed Saltator Saltator aurantiirostris, was positive, yet stronger during the breeding than during the non-breeding season (Table 2, Fig. 3). On the other hand, the relationship between patch isolation and population abundance for Great Antshrike Taraba major was negative and stronger during the breeding than during the nonbreeding season (Table 2, Fig. 3). Finally, the relationship between patch isolation and population abundance for Saffron Finch Sicalis flaveola was positive, yet stronger during the non-breeding season (Table 2, Fig. 3). 
Table 2. Relationship between the explanatory variables selected in the best model and population abundance for overall species, and the subsets of forest species and habitat generalist species, and for each individual species.

\begin{tabular}{|c|c|c|c|c|}
\hline Species & Estimates & se & $t$-value & $P$-value \\
\hline \multicolumn{5}{|l|}{ Species groups } \\
\hline \multicolumn{5}{|l|}{ Overall species } \\
\hline Patch area (log) & 1.844 & 0.663 & 2.781 & 0.017 \\
\hline Season $\times$ Patch area $(\log )$ & 0.703 & 0.674 & 1.043 & 0.317 \\
\hline \multicolumn{5}{|l|}{ Forest species } \\
\hline Patch area (log) & 1.003 & 0.267 & 3.744 & 0.003 \\
\hline Season $\times$ Patch area $(\log )$ & 0.558 & 0.266 & 2.092 & 0.058 \\
\hline \multicolumn{5}{|l|}{ Habitat generalist species } \\
\hline Patch area (log) & 0.84 & 0.532 & 1.58 & 0.142 \\
\hline Season $\times$ Patch area $(\log )$ & 0.145 & 0.619 & 0.235 & 0.818 \\
\hline \multicolumn{5}{|l|}{ Forest species } \\
\hline \multicolumn{5}{|l|}{ Crypturellus tataupa } \\
\hline Patch area (log) & 0.084 & 0.047 & 1.79 & 0.103 \\
\hline Patch isolation (log) & 0.096 & 0.093 & 1.033 & 0.325 \\
\hline Season $\times$ Patch area $(\mathrm{log})$ & 0.154 & 0.061 & 2.504 & 0.029 \\
\hline Season $\times$ Patch isolation (log) & 0.048 & 0.108 & 0.442 & 0.666 \\
\hline \multicolumn{5}{|l|}{ Leptotila verreauxi } \\
\hline Patch area (log) & 0.159 & 0.074 & 2.136 & 0.055 \\
\hline Season $\times$ Patch area $(\log )$ & 0.069 & 0.072 & 0.949 & 0.361 \\
\hline \multicolumn{5}{|l|}{ Colaptes melanochloros } \\
\hline Patch area (log) & 0.059 & 0.0201 & 2.937 & 0.013 \\
\hline Season $\times$ Patch area $(\log )$ & -0.035 & 0.028 & -1.26 & 0.231 \\
\hline \multicolumn{5}{|l|}{ Thamnophilus caerulescens } \\
\hline Patch area (log) & 0.245 & 0.047 & 5.167 & 0.0003 \\
\hline Season $\times$ Patch area $(\mathrm{log})$ & -0.057 & 0.061 & -0.944 & 0.363 \\
\hline \multicolumn{5}{|l|}{ Taraba major } \\
\hline Patch isolation (log) & -0.141 & 0.091 & -1.548 & 0.149 \\
\hline Season $\times$ Patch isolation (log) & -0.237 & 0.103 & -2.281 & 0.041 \\
\hline \multicolumn{5}{|l|}{ Pseudoseisura lophotes } \\
\hline Patch area (log) & 0.137 & 0.041 & 3.307 & 0.007 \\
\hline Season $\times$ Patch area $(\mathrm{log})$ & 0.008 & 0.053 & 0.161 & 0.874 \\
\hline \multicolumn{5}{|l|}{ Stigmatura budytoides } \\
\hline Patch area (log) & 0.106 & 0.036 & 2.882 & 0.014 \\
\hline Season $\times$ Patch area $(\log )$ & -0.07 & 0.052 & -1.346 & 0.202 \\
\hline \multicolumn{5}{|l|}{ Serpophaga subcristata } \\
\hline Season $\times$ Patch area (log) & -0.031 & 0.081 & -0.383 & 0.709 \\
\hline Season $\times$ Patch isolation (log) & 0.056 & 0.104 & 0.537 & 0.601 \\
\hline \multicolumn{5}{|l|}{ Phytotoma rutila } \\
\hline Patch isolation (log) & -0.214 & 0.137 & -1.554 & 0.148 \\
\hline Season $\times$ Patch isolation (log) & 0.034 & 0.176 & 0.195 & 0.847 \\
\hline \multicolumn{5}{|l|}{ Cyclarhis gujanensis } \\
\hline Patch area (log) & 0.104 & 0.045 & 2.287 & 0.043 \\
\hline Season $\times$ Patch area $(\log )$ & 0.123 & 0.064 & 1.908 & 0.08 \\
\hline \multicolumn{5}{|l|}{ Polioptila dumicola } \\
\hline Patch isolation (log) & -0.194 & 0.113 & -1.709 & 0.115 \\
\hline Season $\times$ Patch isolation (log) & 0.060 & 0.145 & 0.415 & 0.685 \\
\hline \multicolumn{5}{|l|}{ Sicalis flaveola } \\
\hline Patch isolation (log) & 0.463 & 0.092 & 4.994 & $<0.001$ \\
\hline Season $\times$ Patch isolation (log) & -0.412 & 0.130 & -3.151 & 0.004 \\
\hline \multicolumn{5}{|l|}{ Coryphospingus cucullatus } \\
\hline Patch area (log) & 0.058 & 0.053 & 1.101 & 0.294 \\
\hline Season $\times$ Patch area $(\log )$ & -0.061 & 0.063 & -0.958 & 0.356 \\
\hline \multicolumn{5}{|l|}{ Poospiza nigrorufa } \\
\hline Patch area (log) & -0.008 & 0.018 & -0.485 & 0.636 \\
\hline Season $\times$ Patch area $(\log )$ & 0.004 & 0.024 & 0.177 & 0.861 \\
\hline
\end{tabular}


Table 2. (continued)

\begin{tabular}{|c|c|c|c|c|}
\hline Species & Estimates & se & $t$-value & $P$-value \\
\hline \multicolumn{5}{|l|}{ Thraupis bonariensis } \\
\hline Patch isolation (log) & -0.152 & 0.139 & -1.091 & 0.286 \\
\hline Season $\times$ Patch isolation (log) & 0.040 & 0.184 & 0.220 & 0.827 \\
\hline \multicolumn{5}{|l|}{ Saltator aurantiirostris } \\
\hline Patch area (log) & 0.146 & 0.09 & 1.62 & 0.133 \\
\hline Season $\times$ Patch area $(\log )$ & 0.267 & 0.082 & 3.254 & 0.006 \\
\hline \multicolumn{5}{|l|}{ Habitat generalist species } \\
\hline \multicolumn{5}{|l|}{ Patagioenas maculosa } \\
\hline Patch area (log) & 0.445 & 0.133 & 3.346 & 0.006 \\
\hline Season $\times$ Patch area $(\log )$ & -0.114 & 0.129 & -0.883 & 0.394 \\
\hline \multicolumn{5}{|l|}{ Patagioenas picazuro } \\
\hline Patch area (log) & 0.186 & 0.07 & 2.637 & 0.023 \\
\hline Season $\times$ Patch area $(\log )$ & -0.134 & 0.073 & -1.82 & 0.093 \\
\hline \multicolumn{5}{|l|}{ Zenaida auriculata } \\
\hline Patch area (log) & 0.026 & 0.115 & 0.229 & 0.822 \\
\hline Season $\times$ Patch area $(\log )$ & 0.106 & 0.100 & 1.061 & 0.309 \\
\hline \multicolumn{5}{|l|}{ Columbina picui } \\
\hline Patch isolation (log) & -0.153 & 0.212 & -0.721 & 0.485 \\
\hline Season $\times$ Patch isolation $(\mathrm{log})$ & -0.028 & 0.257 & -0.109 & 0.914 \\
\hline \multicolumn{5}{|l|}{ Myiopsitta monachus } \\
\hline Patch area (log) & 0.148 & 0.112 & 1.321 & 0.213 \\
\hline Season $\times$ Patch area $(\log )$ & 0.083 & 0.145 & 0.57 & 0.578 \\
\hline \multicolumn{5}{|l|}{ Furnarius rufus } \\
\hline Patch area (log) & -0.011 & 0.044 & -0.256 & 0.802 \\
\hline Season $\times$ Patch area (log) & 0.094 & 0.046 & 2.038 & 0.064 \\
\hline \multicolumn{5}{|l|}{ Pitangus sulphuratus } \\
\hline Patch area (log) & -0.04 & 0.069 & -0.58 & 0.573 \\
\hline Season $\times$ Patch area $(\log )$ & 0.106 & 0.072 & 1.479 & 0.164 \\
\hline \multicolumn{5}{|l|}{ Troglodytes aedon } \\
\hline Patch area (log) & -0.154 & 0.078 & -1.981 & 0.075 \\
\hline Patch isolation (log) & -0.238 & 0.153 & -1.55 & 0.152 \\
\hline Season $\times$ Patch area $(\log )$ & 0.128 & 0.101 & 1.264 & 0.232 \\
\hline Season $\times$ Patch isolation $(\log )$ & 0.263 & 0.179 & 1.472 & 0.168 \\
\hline \multicolumn{5}{|l|}{ Zonotrichia capensis } \\
\hline Patch isolation (log) & -0.192 & 0.152 & -1.266 & 0.236 \\
\hline Season $\times$ Patch isolation $(\log )$ & 0.121 & 0.137 & 0.888 & 0.392 \\
\hline \multicolumn{5}{|l|}{ Agelaioides badius } \\
\hline Patch isolation (log) & 0.241 & 0.181 & 1.333 & 0.209 \\
\hline Season $\times$ Patch isolation $(\log )$ & -0.164 & 0.232 & -0.709 & 0.491 \\
\hline \multicolumn{5}{|l|}{ Molothrus bonariensis } \\
\hline Patch area (log) & 0.119 & 0.092 & 1.288 & 0.226 \\
\hline Patch isolation (log) & 0.194 & 0.183 & 1.063 & 0.312 \\
\hline Season $\times$ Patch area $(\log )$ & -0.271 & 0.121 & -2.237 & 0.046 \\
\hline Season $\times$ Patch isolation (log) & -0.409 & 0.213 & -1.92 & 0.081 \\
\hline \multicolumn{5}{|l|}{ Molothrus rufoaxillaris } \\
\hline Patch area (log) & 0.021 & 0.082 & 0.262 & 0.797 \\
\hline Season $\times$ Patch area $(\mathrm{log})$ & -0.05 & 0.081 & -0.615 & 0.549 \\
\hline
\end{tabular}

$P$-values in bold indicate a statistically significant relationship. 'Estimates' indicate the slope of the relationship between the explanatory variable and the response variable. The estimates of the interaction term indicate how much stronger (if the value was positive) or weaker (if the value was negative) is this relationship during the breeding season relative to the non-breeding season. Therefore, a significant relationship between patch area or isolation and season means that the relationship between forest fragmentation (patch area or isolation) and population abundance is different between the seasons. 




Figure 2. Relationship between forest patch area and population abundance of three groups of bird species (overall species, forest species and habitat generalist species), both during the breeding season (three plots located on the left hand side of the figure) and during the non-breeding season (three plots located on the right hand side of the figure). An asterisk indicates a statistically significant relationship $(P<0.05$; see Table 2$)$. Confidence intervals of $95 \%$ are shaded in grey.

The species-by-species analysis for habitat generalists showed that the population abundances of Spot-winged Pigeon Patagioenas maculosa and Picazuro Pigeon Patagioenas picazuro were positively related to patch area, independently of the season (Table 2). On the other hand, the relationship between patch area and population abundance for Shiny Cowbird Molothrus bonariensis was different across seasons: a negative relationship was observed only during the breeding season. That is, the species was more abundant in smaller patches than in larger patches during the breeding season (Table 2, Fig. 3).

\section{DISCUSSION}

Most bird species in this study are relatively common, both locally and regionally (Yzurieta 1995, Salvador et al. 2016). However, summed abundance over all species was negatively related to patch area during both the breeding and the non-breeding seasons. It is important to highlight negative responses of common bird species to forest fragmentation because several studies in conservation biology generally focus on rare or threatened species, disregarding common ones (Gaston 2008, Gaston \& Fuller 2008). Moreover, it is important to point out that the size of the smallest patches in this study closely represents the mean area of forest patches in the northwest (7.3 ha) and northeast of Cordoba province (1.5 ha; Hoyos et al. 2013). Therefore, the decrease in population abundance in relation to forest fragmentation observed locally for common bird species in the study area may be evidence of a generalized situation that the avifauna faces across the Chaco region.

At the broadest level of analysis (considering the overall species studied in the community), 


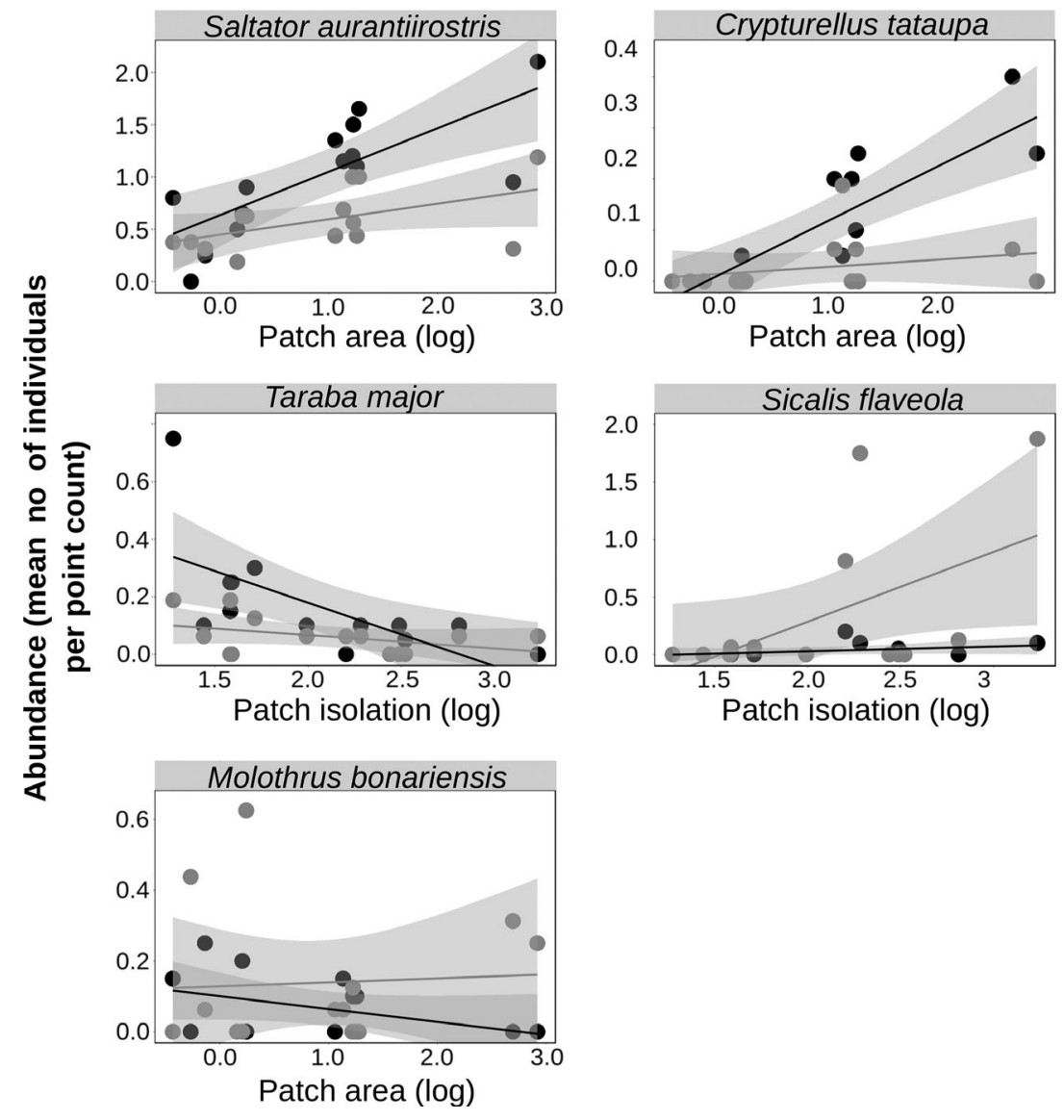

Figure 3. Relationship between forest fragmentation (patch area or patch isolation) and population abundance for those species which showed a differential response across seasons. Black dots and lines represent abundances during the breeding season, and grey dots and lines represent abundances during the non-breeding season. Confidence intervals of $95 \%$ are shaded in grey.

forest fragmentation seems to affect bird populations independently of season. Several studies suggest that patch area reduction is one of the main factors explaining population declines in the context of forest fragmentation (Watson et al. 2004, Bregman et al. 2014, Modest et al. 2016). Patch area reduction can lead to food shortage, which in turn can negatively affect bird population abundances (Zanette et al. 2000, but see Verga et al. 2017). Moreover, the reduction of patch area is correlated with an increase of the patch edge-area ratio. Many environmental conditions change near the forest edges, such as temperature, moisture, vegetation structure and biotic interaction (Ewers \& Banks-Leite 2013), and these can negatively affect bird populations (Banks-Leite et al. 2010).

At a lower level of analysis, the fact that we found different responses of bird populations to forest fragmentation depending on them being forest or habitat generalist species was as expected (Morante-Filho et al. 2015, Asefa et al. 2017). Habitat generalist species appear to be resilient to forest fragmentation, possibly because they are able to use different elements of the landscape, such as open areas, isolated trees or even the agriculture matrix. However, it was less expected that only some forest species would respond differently to forest fragmentation between seasons. Species that showed a different response to forest fragmentation seem to be more sensitive during the breeding season (Golden-billed Saltator, Great Antshrike, Tataupa Tinamou and Saffron Finch). This pattern could be explained by different factors. For example, the increase of the spatial range of daily movements during the non-breeding season (Wiktander et al. 2001, Lenz et al. 2015) implies that the probability of individual occurrences in an isolated or small forest patch would 
be greater during that season than during the breeding season. Hence, during the non-breeding season, it is expected that the effect of patch area reduction or patch isolation on bird population would be weaker than in the breeding season (Evans et al. 2013, Lenz et al. 2015).

The seasonal changes in the matrix used by some species may also be important in understanding seasonal differences in bird responses to forest fragmentation. During the winter there are some agricultural fields without crop production, so the matrix is composed of stubble fields. This type of matrix can offer food resources, such as seeds and invertebrate fauna, which are consumed by granivorous-insectivorous bird species (Moorcroft et al. 2002, Whittingham et al. 2006). Therefore, there are species that use stubble fields as an alternative foraging area during the non-breeding season (Moorcroft et al. 2002). For example, Goldenbilled Saltator (whose response to forest fragmentation was weaker during the non-breeding season), forages on stubble fields near forest patches at this time of year (E. G. Verga pers. obs.). This expansion of the foraging habitat during the winter could ameliorate the negative effects of patch area reduction or isolation, relative to the summer when birds spend most of their time within forest patches.

Shiny Cowbird was another species for which we found a different response to forest fragmentation between seasons. The species showed greater abundance in smaller forest patches, yet this pattern was observed only during the breeding season (see Table 2 and Fig. 3 for details). Shiny Cowbird is a generalist brood parasite which lays eggs in the nests of at least 232 different avian species (Reboreda et al. 2003). Our results suggest that the incidence of brood parasitism may be greater in small forest patches, where this species is more abundant (Dardanelli et al. 2006). Furthermore, our results provide additional support for the hypothesis that a key mechanism to explain bird population decline in fragmented forests is brood parasitism (Paton 1994, Robinson et al. 1995, Stratford \& Robinson 2005).

Interestingly, there were no bird species or groups of species studied here that only showed a negative population response to forest fragmentation during the non-breeding season. However, in this study, we have considered only a local scale (patch level). Therefore, we do not know whether bird responses are weaker during the non-breeding season or whether birds may be responding at a larger spatial scale that we did not consider. As birds tend to increase the distances travelled and the size of their home-range during the winter (Wiktander et al. 2001, Lenz et al. 2015), the spatial scale of response to forest fragmentation may also change throughout the year. Future studies could assess the scale of effect, that is, the spatial extent at which landscape structure has the highest correlation with the response variable (e.g. population abundance; for details of the study design see Jackson \& Fahrig 2015), and could assess whether this scale of effect is greater during the non-breeding season.

\section{CONCLUSIONS AND CONSERVATION REMARKS}

Chaco forest is one of the regions most threatened by agricultural expansion worldwide (Hansen et al. 2013, Schmidt 2015) and its rate of forest clearance shows an increasing trend in the last 30 years (Vallejos et al. 2015). In this context of accelerated habitat loss, all forest patches, including the smallest ones, are of conservation value. However, considering that overall bird abundance is lower in smaller patches during both the breeding and the non-breeding seasons, major conservation efforts should be focused on the largest forest patches. Moreover, larger forest patches harbour three times greater population abundances of forest species compared with smaller ones (see Fig. 2 for details). Because mean patch area in the study region is relatively small (between 1.5 and 7 ha; Hoyos et al. 2013), there is an urgent necessity to conserve the remnant large patches of native forest in the area. However, we should not discount the conservation value of smaller patches as, at least during the non-breeding season, such patches may also be important elements to maintain the population of some bird species in fragmented landscapes. Additionally, restoration efforts with native vegetation should be carried out to increase the mean size of forest patches.

We are grateful to Ma. Lucrecia Herrero for her help in the field, and to Mariana Pereyra, Gabriel Grilli and Pablo Huais for enriching discussions that improved the manuscript. We thank Estancia Santo Domingo and Comuna de Tinoco for allowing us to work on their properties. We are grateful to Alicia and her family for their hospitality and for providing lodging at one of the study sites. We also thank two anonymous reviewers 
and Inês Catry for their efforts in reviewing an early version of the manuscript, which greatly helped to improve it. We thank Consejo Nacional de Investigaciones Científicas y Técnicas (CONICET), FONCyT and SECyT (Universidad Nacional de Córdoba) for financial support. L.G. and S.I.P. are researchers at CONICET, serving as professors at the Universidad Nacional de Córdoba. E.G.V. is a CONICET fellowship holder.

\section{Data availability statement}

The data that support the findings of this study are available from the corresponding author (E.G.V) upon reasonable request.

\section{REFERENCES}

Asefa, A., Davies, A.B., McKechnie, A.E., Kinahan, A.A. \& van Rensburg, B.J. 2017. Effects of anthropogenic disturbance on bird diversity in Ethiopian montane forests. Condor 119: 416-430.

Banks-Leite, C., Ewers, R.M. \& Metzger, J. 2010. Edge effects as the principal cause of area effects on birds in fragmented secondary forest. Oikos 119: 918-926.

Bartoń, K. 2016. MuMIn: Multi-Model Inference. $R$ package version 1.15.6. Available at: https://CRAN.R-project.org/pac kage=MuMIn (accessed 4 June 2019).

Bennett, A.F., Radford, J.Q. \& Haslem, A. 2006. Properties of land mosaics: implications for nature conservation in agricultural environments. Biol. Conserv. 133: 250-264.

Bregman, T.P., Sekercioglu, C.H. \& Tobias, J.A. 2014. Global patterns and predictors of bird species responses to forest fragmentation: implications for ecosystem function and conservation. Biol. Conserv. 169: 372-383.

Bucher, E. 1982. Chaco and Caatinga - South American arid savannas, woodlands and thickets. Ecol. Stud. 42: 48-79.

Cabido, M., Zeballos, S.R., Zak, M., Carranza, M.L., Giorgis, M.A., Cantero, J.J. \& Acosta, A.T.R. 2018. Native woody vegetation in central Argentina: classification of Chaco and Espinal forests. Appl. Veg. Sci. 21: 298-311.

Caprio, E., Ellena, I. \& Rolando, A. 2009. Assessing habitat/ landscape predictors of bird diversity in managed deciduous forests: a seasonal and guild-based approach. Biodivers. Conserv. 18: 1287-1303.

Dardanelli, S., Nores, M.L. \& Nores, M. 2006. Minimum area requirements of breeding birds in fragmented woodland of Central Argentina. Divers. Distrib. 12: 687-693.

Díaz Vélez, M.C., Silva, W.R., Pizo, M.A. \& Galetto, L. 2015. Movement patterns of frugivorous birds promote functional connectivity among Chaco Serrano woodland fragments in Argentina. Biotropica 47: 475-483.

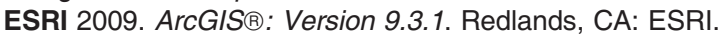

Evans, D.M., Levey, D.J. \& Tewksbury, J.J. 2013. Landscape corridors promote long-distance seed dispersal by birds during winter but not during summer at an experimentally fragmented restoration site. Ecol. Restor. 31: 23-30.

Ewers, R.M. \& Banks-Leite, C. 2013. Fragmentation impairs the microclimate buffering effect of tropical forests. PLOS ONE 8, e58093.
Fardila, D., Kelly, L.T., Moore, J.L. \& McCarthy, M.A. 2017. A systematic review reveals changes in where and how we have studied habitat loss and fragmentation over 20 years. Biol. Conserv. 212: 130-138.

Ferreras, A.E. \& Galetto, L. 2010. From seed production to seedling establishment: important steps in an invasive process. Acta Oecol. 36: 211-218.

Ferreras, A.E., Torres, C. \& Galetto, L. 2008. Fruit removal of an invasive exotic species (Ligustrum lucidum) in a fragmented landscape. J. Arid Environ. 72: 1573-1580.

Fraixedas, S., Lehikoinen, A., Lindén, A. \& Coastal, A. 2015. Impacts of climate and land-use change on wintering bird populations in Finland. J. Avian Biol. 46: 63-72.

Gaston, K.J. 2008. Biodiversity and extinction: the importance of being common. Prog. Phys. Geogr. 32: 73-79.

Gaston, K.J. \& Fuller, R.A. 2008. Commonness, population depletion and conservation biology. Trends Ecol. Evol. 23: 14-19.

Gavier, G.I. \& Bucher, E.H. 2004. Deforestación de las Sierras Chicas de Córdoba (Argentina) en el período 1970 1997. Acad. Nac. Ciencias 101: 3-27.

Gill, F. \& Donsker, D. (eds) 2019. IOC World Bird List (v 9.1). https://doi.org/10.14344/IOC.ML.9.1. Available at: http:// www.worldbirdnames.org/ (accessed 23 May 2019).

Giraudo, L., Kufner, M., Torres, R., Tamburini, D., Briguera, V. \& Gavier, G. 2006. Avifauna del bosque chaqueño oriental de la provincia de Córdoba, Argentina. Ecol. Apl. 5: 127-136.

González, E., Buffa, L., Defagó, M.T., Molina, S.I., Salvo, A. \& Valladares, G. 2018. Something is lost and something is gained: loss and replacement of species and functional groups in ant communities at fragmented forests. Landsc. Ecol. 33: 2089-2102.

Grilli, G. \& Galetto, L. 2009. Remoción de frutos de una especie invasora (Lantana camara L.) en el Bosque Chaqueño de Córdoba (Argentina). Ecol. Austral 19: 149-156.

Grilli, G., Urcelay, C. \& Galetto, L. 2013. Linking mycorrhizal fungi and soil nutrients to vegetative and reproductive ruderal plant development in a fragmented forest at central Argentina. For. Ecol. Manage. 310: 442-449.

Grilli, G., Urcelay, C., Longo, M.S. \& Galetto, L. 2014. Mycorrhizal fungi affect plant growth: experimental evidence comparing native and invasive hosts in the context of forest fragmentation. Plant Ecol. 215: 1513-1525.

Hansen, M.C., Potapov, P.V., Moore, R., Hancher, M., Turubanova, S.A., Tyukavina, A., Thau, D., Stehman, S.V., Goetz, S.J., Loveland, T.R., Kommareddy, A., Egorov, A., Chini, L., Justice, C.O. \& Townshend, J.R.G. 2013. High-resolution global maps of 21 st-century forest cover change. Science 342: 850-853.

Henle, K., Davies, K.F., Kleyer, M., Margules, C. \& Settele, J. 2004. Predictors of species sensitivity to fragmentation. Biodivers. Conserv. 13: 207-251.

Hoyos, L.E., Cingolani, A.M., Zak, M.R., Vaieretti, M.V., Gorla, D.E. \& Cabido, M.R. 2013. Deforestation and precipitation patterns in the arid Chaco forests of central Argentina. Appl. Veg. Sci. 16: 260-271.

Jackson, H.B. \& Fahrig, L. 2015. Are ecologists conducting research at the optimal scale? Glob. Ecol. Biogeogr. 24: 52-63.

Keller, G.S. \& Yahner, R.H. 2007. Seasonal forest-patch use by birds in fragmented landscapes of south-central Pennsylvania. Wilson J. Ornithol. 119: 410-418. 
Lenz, J., Böhning-Gaese, K., Fiedler, W. \& Mueller, T. 2015. Nomadism and seasonal range expansion in a large frugivorous bird. Ecography 38: 54-62.

Lewis, J.P., Noetinger, S., Prado, D.E. \& Barberis, I.M. 2009. Woody vegetation structure and composition of the last relicts of Espinal vegetation in subtropical Argentina. Biodivers. Conserv. 18: 3615-3628.

Modest, R.B., Hassan, S.N. \& Rija, A.A. 2016. Spatial metrics effect of forest fragmentation on forest bird abundance and site occupancy probability: the influence of patch size and isolation. Ostrich 87: 131-138.

Moorcroft, D., Whittingham, M.J., Bradbury, R.B. \& Wilson, J.D. 2002. The selection of stubble fields by wintering granivorous birds reflects vegetation cover and food abundance. J. Appl. Ecol. 39: 535-547.

Morante-Filho, J.C., Faria, D., Mariano-neto, E. \& Rhodes, J. 2015. Birds in anthropogenic landscapes: the responses of ecological groups to forest loss in the Brazilian Atlantic forest. PLOS ONE 10: 1-18.

Morgado, R., Beja, P., Reino, L., Gordinho, L., Delgado, A., Borralho, R. \& Moreira, F. 2010. Calandra lark habitat selection: strong fragmentation effects in a grassland specialist. Acta Oecol. 36: 63-73.

Murgui, E. 2007. Effects of seasonality on the species-area relationship: a case study with birds in urban parks. Glob. Ecol. Biogeogr. 16: 319-329.

Naoe, S., Sakai, S., Sawa, A. \& Masaki, T. 2011. Seasonal difference in the effects of fragmentation on seed dispersal by birds in Japanese temperate forests. Ecol. Res. 26: 301-309.

Naoe, S., Sakai, S. \& Masaki, T. 2012. Effect of forest shape on habitat selection of birds in a plantation-dominant landscape across seasons: comparison between continuous and strip forests. J. For. Res 17: 219-223.

Nour, N., van Damme, R., Matthysen, E. \& Dhondt, A. 1999. Forest birds in forest fragments: are fragmentation effects independent of season? Bird Study 46: 37-41.

Paton, P.W. 1994. The effect of edge on avian nest success: how strong is the evidence? Conserv. Biol. 8: 17-26.

Pinheiro, J., Bates, D., DebRoy, S. \& Sarkar, D. 2015. nlme: Linear and Nonlinear Mixed Effects Models. $R$ package version 3.1-131. Available at: https://CRAN.R-project.org/pac kage=nlme (accessed 4 June 2019).

R Core Team 2016. R: A Language and Environment for Statistical Computing. Vienna, Austria: R Foundation for Statistical Computing. Available at: https://www.R-project.org/

Radford, J.Q. \& Bennett, A.F. 2004. Thresholds in landscape parameters: occurrence of the white-browed treecreeper Climacteris affinis in Victoria, Australia. Biol. Conserv. 117: 375-391.

Reboreda, J.C., Mermoz, M., Massoni, V., Astié, A.A. \& Rabuffetti, F.L. 2003. Impacto del parasitismo de cría del tordo renegrido (Molothrus bonariensis) sobre el éxito reproductivo de sus hospedadores. Hornero 18: 77-88.

Robb, G.N., McDonald, R.A., Chamberlain, D.E., Reynolds, S.J., Harrison, T.J.E. \& Bearhop, S. 2008. Winter feeding of birds increases productivity in the subsequent breeding season. Biol. Lett 4: 220-223.

Robinson, S.K., Thompson, F.R., Donovan, T.M., Whitehea, D.R. \& Faaborg, J. 1995. Regional forest fragmentation and the nesting success of migratory birds. Science 267: 1987 1990.

Salvador, S.A., Salvador, L.A., Ferrari, C. \& Vitale, S. 2016. Listado de aves de la provincia de Córdoba, Argentina. Argentina Bird Checklist. 1-31.

Schmidt, M.H. 2015. Política ambiental, avance de la frontera agropecuaria y deforestación en Argentina: el caso de la ley "De Bosques". Rev. GeoPantanal 18: 121-139.

Siffczyk, C., Brotons, L., Kangas, K. \& Orell, M. 2003. Home range size of willow tits: a response to winter habitat loss. Oecologia 136: 635-642.

Stratford, J.A. \& Robinson, W.D. 2005. Gulliver travels to the fragmented tropics: geographic variation in mechanisms of avian extinction. Front. Ecol. Environ. 3: 91-98.

Turner, I. 1996. Species loss in fragments of tropical rain forest: a review of the evidence. J. Appl. Ecol. 33: 200209.

Vallejos, M., Volante, J.N., Mosciaro, M.J., Vale, L.M., Bustamante, M.L. \& Paruelo, J.M. 2015. Transformation dynamics of the natural cover in the Dry Chaco ecoregion: a plot level geo-database from 1976 to 2012. J. Arid Environ. 123: 3-11.

Verga, E.G., Hümöller, H.L.S., Peluc, S.I. \& Galetto, L. 2017. Forest fragmentation negatively affects common bird species in subtropical fragmented forests. Emu - Austral Ornithol. 117: 359-369.

Watson, J.E.M., Whittaker, R.J. \& Dawson, T.P. 2004. Avifaunal responses to habitat fragmentation in the threatened littoral forests of south eastern Madagascar. J. Biogeogr. 31: 1791-1807.

Whittingham, M.J., Devereux, C.L., Evans, A.D. \& Bradbury, R.B. 2006. Altering perceived predation risk and food availability: management prescriptions to benefit farmland birds on stubble fields. J. Appl. Ecol. 43: 640-650.

Wiktander, U., Olsson, O. \& Nilsson, S.G. 2001. Seasonal variation in home-range size, and habitat area requirement of the lesser spotted woodpecker (Dendrocopos minor) in southern Sweden. Biol. Conserv. 100: 387-395.

Yamaura, Y., Ikeno, S., Sano, M., Okabe, K. \& Ozaki, K. 2009. Bird responses to broad-leaved forest patch area in a plantation landscape across seasons. Biol. Conserv. 142: 2155-2165.

Yzurieta, D. 1995. Manual de Reconocimiento y Evaluación Ecológica de las aves de Córdoba. Argentina: Córdoba.

Zak, M.R., Cabido, M. \& Hodgson, J.G. 2004. Do subtropical seasonal forests in the Gran Chaco, Argentina, have a future? Biol. Conserv. 120: 589-598.

Zanette, L., Doyle, P. \& Trémont, S.M. 2000. Food shortage in small fragments: evidence from an area-sensitive passerine. Ecology 81: 1654-1666.

Zuur, A.F., leno, E.N., Walker, N.J., Saveliev, A.A. \& Smith, G.M. 2009. Mixed Effects Models and Extensions in Ecology with $R$. New York, NY: Springer.

Received 11 March 2019; revision accepted 4 March 2020 Associate Editor: Inês Catry. 


\section{SUPPORTING INFORMATION}

Additional supporting information may be found online in the Supporting Information section at the end of the article.

Figure S1. Landscape of the study area, where forest patches of different size are immersed in an agricultural matrix.
Table S1. Total avian species registered in the study area, during both the breeding and the nonbreeding seasons, within the 14 studied patches. 